\title{
Spawning patterns of commercially important reef fish (Lutjanidae and Serranidae) in the tropical western South Atlantic
}

\author{
MATHEUS OLIVEIRA FREITAS ${ }^{1}$, RODRIGO LEÃO DE MOURA ${ }^{2}$, RONALDO BASTOS \\ FRANCINI-FILHO $^{3}$ and CAROLINA VIVIANA MINTE-VERA ${ }^{4}$ \\ ${ }^{1}$ Grupo de Pesquisa em Ictiofauna, Museu de História Natural Capão da Imbuia. Laboratório de Ictiologia, \\ Rua Prof. Benedito Conceição, 407, Curitiba, PR, 82810-080, Brazil. \\ ${ }^{2}$ Conservation International Brazil, Marine Program, Rua das Palmeiras 451, Caravelas, BA, 45900-000, Brazil. \\ E-mail: r.moura@conservation.org \\ ${ }^{3}$ Departamento de Engenharia e Meio Ambiente, Centro de Ciểncias Aplicadas e Educação, \\ Universidade Federal da Paraíba, Rua da Mangueira, s/n, Rio Tinto, PB, 58297-000, Brazil \\ ${ }^{4}$ Universidade Estadual de Maringá, Núcleo de Pesquisas em Limnologia, Ictiologia e Aqüicultura, Avenida Colombo \\ 5790, Bloco H-90, Maringá, PR, 87020-900, Brazil.
}

SUMMARY: Although information on the spawning seasons of commercially important snappers (Lutjanidae) and groupers (Serranidae, subfamily Epinephelinae) is available for the north and central west Atlantic, there is little information for the tropical western South Atlantic (Brazil). As a consequence, there are few fishery regulations in this entire region that take into consideration such information. In this study, we characterized the reproductive cycles of three Epinephelinae serranids (Epinephelus morio, Mycteroperca bonaci and Cephalopholis fulva) and five lutjanids (Lutjanus synagris, L. jocu, L. analis, Ocyurus chrysurus and Rhomboplites aurorubens) that occur in the Abrolhos Bank, Brazil, the largest reef complex in the tropical western South Atlantic. A total of 3528 gonads were collected from May 2005 to October 2007. Temporal variability in spawning patterns was evaluated using the Gonadosomatic Index (GSI) and macroscopic analyses. The peak of reproductive activity for the three grouper species occurred between July and August. Snappers exhibited two peaks of reproductive activity, the more intense of which occurred between September and October. The other peak occurred between February and March, with the exception of the deep-dwelling species $R$. aurorubens, which only reproduced between February and March. Seasonal patterns were consistent over the two consecutive years that we studied, and these patterns are equivalent to those observed for the Northern Hemisphere, as are the sizes at maturity and at the time of sexual change (for the three protogynous hermaphrodite groupers). Fisheries management in this region could be significantly improved by a combination of catch and effort limitations being imposed during spawning seasons and by overall size limitations, particularly considering that most of the fish caught are generally below size at maturity. The proposed buffer zones for the marine areas that are presently protected in Abrolhos represent an opportunity for implementing both spatial (e.g. setting no-take zones that cover spawning sites) and temporal (e.g. seasonal closures during spawning peaks) management tools, using a participatory approach at the regional scale.

Keywords: small-scale fisheries management, reproduction, reef fisheries, Abrolhos Bank, Brazil.

RESUMEN: PATRones de DESOVE DE PECES DE ARRECIFE COMERCIALMENTE IMPORTANTES (LUTJANIDAE Y SERRANIDAE) en el Atlántico tropical suroccidental. - A pesar de que se tiene un buen conocimiento sobre la época de freza de los pargos (Lutjanidae) y los meros (Serranidae, subfamilia Epinephelinae) en las zonas norte y central del Atlántico occidental, la información disponible del Atlántico suroccidental es escasa. Como consecuencia, en esta zona aún existen pocas regulaciones pesqueras que tengan en cuenta esta información. En este estudio se caracterizan los ciclos reproductores de tres serránidos Epinephelinae (Epinephelus morio, Mycteroperca bonaci and Cephalopholis fulva) y cinco pargos (Lutjanus synagris, L. jocu, L. analis, Ocyurus chrysurus and Rhomboplites aurorubens) en el Banco de Abrolhos, el mayor complejo de arrecifes del Atlántico suroccidental. Se examinaron un total de 3528 gónadas entre mayo de 2005 y octubre de 2007 . La variabilidad temporal de las pautas de puesta se evaluó mediante el Índice Gonadosomático (GSI) y análisis microscópicos. Para los tres meros el máximo en la actividad reproductora se produce entre julio y agosto. Los lutjánidos presentan dos picos 


\begin{abstract}
de actividad bien diferenciados, siendo el más intenso el que tiene lugar entre septiembre y octubre, mientras que el menor se produce entre febrero y marzo, con la excepción de $R$. aurorubens, una especie de profundidad, que sólo se reproduce entre febrero y marzo. Las pautas estacionales en la reproducción son consistentes en los dos años consecutivos y, junto a la edad de primera madurez y la edad de inversión sexual (los tres meros son hermafroditas proterogínicos), son equivalentes a las que se producen en el hemisferio septentrional. La gestión pesquera en esta región podría mejorar significativamente mediante una combinación de limitaciones en las capturas y en el esfuerzo durante las épocas de puesta, así como limitando la talla mínima de captura, considerando que la mayoría de individuos capturados actualmente son inmaduros. Las zonas de amortiguación de las áreas marinas actualmente protegidas en Abrolhos representan una buena oportunidad para implementar herramientas de gestión tanto espaciales (e.g. estableciendo zonas de exclusión pesquera en los lugares de freza) como temporales (e.g. prohibiendo la pesca durante la época de reproducción), utilizando una aproximación participativa a una escala regional.
\end{abstract}

Palabras clave: gestión de pesquerías a pequeña escala, reproducción, pesquerías en los arrecifes, banco de Abrolhos, Brasil.

\section{INTRODUCTION}

Fish from the families Lutjanidae (snappers) and Serranidae, and in particular members of the subfamily Epinephelinae (groupers), comprise some of the most important fishery resources in the tropical west Atlantic and also play a major role as predators in reef ecosystems (Allen, 1985; Polovina and Ralston, 1987; Heemstra and Randall, 1993; Claro et al., 2001). Due to several similarities regarding fishing grounds and gear, as well as their long-lived and large-sized nature, these species are referred to collectively as the "snapper-grouper complex" (e.g. Coleman et al., 1999, 2000; Gobert et al., 2005). Following worldwide trends for marine fisheries (Pauly et al., 2005; Pauly, 2009), most snapper-grouper fisheries are sharply declining, collapsing or already depleted (Morris et al., 2000; Frédou and Ferreira, 2005). This trend includes fisheries that have been intensively researched and managed (Coleman et al., 2000). Due to the concentrated nature of reproductive events for several species in this group, spawning aggregations of snappers and groupers are currently disappearing even before scientists and managers realize that they exist (e.g. Colin et al., 2003; Sadovy de Mitcheson et al., 2008).

Fifteen species of snappers and 18 species of Epinephelinae groupers occur off the tropical coast of Brazil (Menezes et al., 2003). All but one snapper species is shared with the North and Central Atlantic (Moura and Lindeman, 2007). Though Brazil encompasses a major portion of the distribution ranges of several commercially important West Atlantic reef fish (Moura, 2003), information about their biology, spawning patterns and fisheries in the Southern Hemisphere is still limited, and information about reproductive cycles is restricted to only a few species and localities (Gesteira and Rocha, 1976 and Sousa-Junior et al., 2008 - Lutjanus synagris; Teixeira et al., 2004 Mycteroperca bonaci; Costa et al., 2003, 2005 - Ocyurus chrysurus; Gerhardinger et al., 2009 - Epinephelus itajara). It is of note that there is a bias towards biological studies of the southern red snapper, Lutjanus purpureus (e.g. Gesteira and Ivo, 1973; Furtado-Junior and Brito, 2002; Souza et al., 2003), which is a species that sustained important fisheries during the 1960 s and 1970s and which is now of minor commercial importance due to overfishing of its main reproductive areas in Brazil (Rezende et al., 2003; Frédou et al., 2009).
Comparing intraspecific variation in spawning patterns among geographically separated regions provides clues for identifying biological, climatic and oceanographic factors that influence the reproductive patterns of snappers and groupers (e.g. Manickchand-Heileman and Phillip, 1999; Claro et al., 2001). This information can also be used to develop valuable management strategies for multispecific fisheries that encompass different geographical regions. In this study, we present the first multi-species assessment of spawning patterns within the poorly studied Brazilian snapper-grouper complex based on a two-year sampling program in the Abrolhos Bank, the largest and richest coral reef complex in the South Atlantic (Moura and Francini-Filho, 2006). We compared the considerable amount of information regarding reproductive patterns of snappers and groupers in the North and Central Atlantic (e.g. Munro et al., 1973; Coleman et al., 1999, 2000; Claro et al., 2001, Claro and Lindeman, 2003; Colin et al., 2003) with our data and with other data from the western South Atlantic, providing the first multi-species appraisal of whether western South Atlantic spawning patterns are equivalent to those in the northwestern Atlantic. We emphasize the need for regional level management measures, such as size and seasonal restrictions, to complement the fleet regulations recently proposed by Frédou et al. (2009a, b).

\section{MATERIALS AND METHODS}

\section{Study region}

Brazilian reefs are a conservation priority in the Atlantic Ocean due to high endemism levels (about 25\% in fish and 50\% in corals) that are concentrated in only 5\% of West Atlantic reefs (Moura, 2003). Artisanal small-scale fisheries account for an estimated $70 \%$ of total fish landings on Brazil's northeastern coast, and these mainly target demersal reef and shore fish and lobsters (Cordell, 2006; Frédou et al., 2006). This study was carried out in the Abrolhos Bank, Bahia State, which covers a wide part $\left(46000 \mathrm{~km}^{2}\right)$ of the continental shelf. The shelf rarely exceeds $30 \mathrm{~m}$, and the shelf edge is at approximately $70 \mathrm{~m}$ depth $\left(16^{\circ} 40^{\prime}-19^{\circ} 40^{\prime} \mathrm{S}\right.$, $39^{\circ} 10^{\prime}-37^{\circ} 20^{\prime} \mathrm{W}$; Fig. 1 ). The study region comprises the largest and richest coral reefs in the South Atlantic, with nearly 300 species of fish and 20 species of reefbuilding corals, as well as an extensive mosaic of algal 


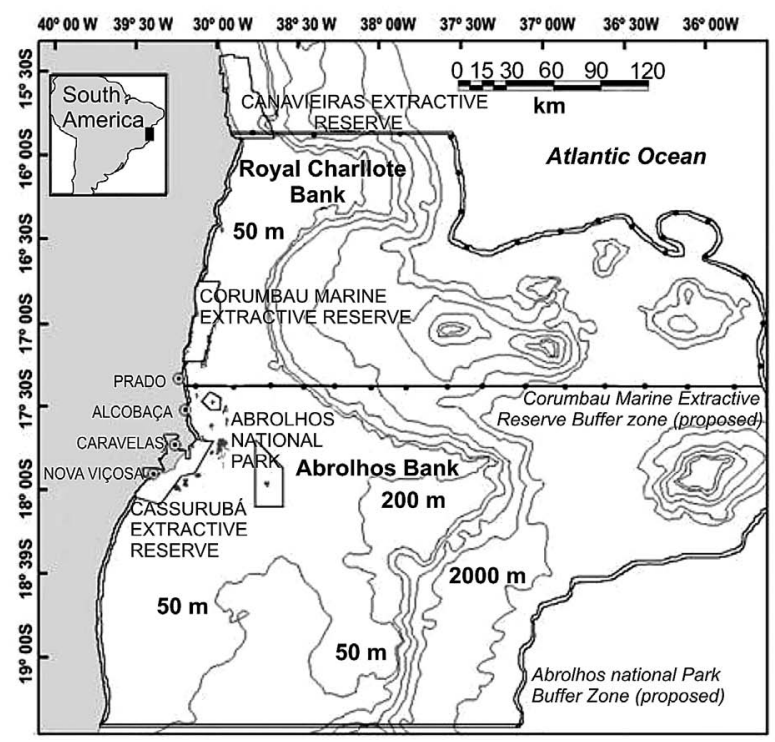

FIG. 1. - Map of the study region showing the Royal Charlotte Bank and the Abrolhos Bank, as well as the marine protected areas and shallow $(<30 \mathrm{~m})$ coral reefs.

bottoms, mangrove forests, beaches and vegetated sandbanks (Moura and Francini-Filho, 2006). Nearly 20000 artisanal fishermen operate in the Abrolhos Bank, but little is known about the region's fisheries and these were not included in recent revisions of data on reef fisheries in northeastern Brazil (Frédou et al., 2006, 2009a, b).

\section{Sampling and analytical methods}

Monthly surveys focusing on hand line, longline and spearfishing landings were carried out at the four main coastal municipalities within the study region (Prado, Alcobaça, Caravelas and Nova Viçosa; Fig. 1) between May 2005 and July 2007. Specimens were measured to the nearest millimetre (total and standard length, TL and SL respectively), sexed, and weighed to the nearest $0.1 \mathrm{~g}$, including total and gutted weight (TW and GW respectively) and gonad weight (GNW). Comparisons with data from the literature were based on fork lengths (FL). Maturity was detected macroscopically based on gonad size, consistency, colour, vascularization, presence of lateral sperm sinuses, ovarian cavity, ovarian lamellae and identifiable oocytes (Munro, 1983; Colin et al., 2003). Sex ratio was estimated using the operational criterion (i.e. only adults included) (Polovina and Ralston, 1987).

The seasonality of gonad development was analyzed with the Gonadosomatic Index (GSI). Analysis of Covariance (ANCOVA) was used to evaluate the monthly variation in the GSI, with log-transformed values of GW for females as covariates, the month as the main effect, and log-transformed values of GNW as the dependent variable. Since body size was positively correlated with $\mathrm{GW}$ values for all species studied, the covariance model was used to estimate GSI for each month.
The smallest size class at which $50 \%$ of fish were sexually mature $\left(\mathrm{L}_{50}\right)$ was estimated separately for males and females by fitting the logistic function with a maximum likelihood estimation (Roa, 1993), using the following binomial likelihood function:

$$
L(\hat{p} \mid x)=\sum_{i=1}^{M} x_{i} \ln \left(\hat{p}_{i}\right)+\left(n_{i}-x_{i}\right) \ln \left(1-\hat{p}_{i}\right)
$$

where $\hat{p}$ is the predicted maturity at length class $i$ given by the logistic function, $x_{i}$ is the number of mature fish, $n_{i}$ is the total number of fish in length class $i$, and $M$ is the total number of size classes. Calculations were performed using the ADMB software (Otter-Research, 2000). For species with a limited sample size, the maximum size of immature specimens and the minimum size of mature specimens were assessed. Size at sexual transformation for the three protogynous hermaphrodite serranids was first estimated by examining sexrelated length frequency distributions.

Semi-structured interviews were carried out with fishermen who had more than ten years of fishing experience in the region, including representatives from Prado, Alcobaça and Caravelas. The interviews were designed to assess local knowledge on temporal and spatial reproductive patterns of snappers and groupers. We asked whether and when each of the studied species spawns and/or forms aggregations. Simple maps of the region were presented during interviews to help fishermen recognize the different fishing grounds. After the results were consolidated, follow-up meetings were convened in the main fishing localities to discuss possible management interventions.

\section{RESULTS}

A total of 3528 specimens were obtained from the four most common snappers (Lutjanus synagris, Lutjanus jocu, Ocyurus chrysurus, Rhomboplites aurorubens) and the three most common groupers (Cephalopholis fulva, Epinephelus morio, Mycteroperca bonaci) (Table 1). Two other snapper species (Lutjanus analis, Lutjanus vivanus) and three groupers (Mycteroperca venenosa, Cephalopholis furcifer, Alphestes afer) were only occasionally landed and sampled (169 specimens; Table 1); therefore, the covariance model could not be used for these species.

Gutted weight (GW) covaried significantly with GSI for all species in both families (Table 2), with the exception of Mycteroperca bonaci. Temporal variability in GSI values was highly significant for all species, also with the exception of M. bonaci (Fig. 2). The weak covariations observed for $M$. bonaci may be related to the low sample size (22 females). Length-weight (LW) and length-length (LL) equations are provided in Table 3.

All lutjanids are gonochoristic (i.e. have separate sexes), and the four species that we studied had a sex ratio approaching 1:1 (Table 1). Spawning of Lutjanus synagris spanned from the Southern Hemisphere 
TABLE 1. - Total sample size, number of non-immature individuals in the sample, and sex ratio for the most frequent species of snapper (Lutjanidae) and groupers (Serranidae) in the Abrolhos Bank reef fisheries. The * indicates species included in the GSI analyses. $\mathrm{p}_{\odot}$ refers to the proportion of females, se is the standard error of $\mathrm{p}_{\text {o }}$

\begin{tabular}{|c|c|c|c|c|c|c|}
\hline & $\mathrm{N}$ & & ture) & sex ratio & $\mathbf{P}_{+}$ & $\mathrm{se}$ \\
\hline \multicolumn{7}{|l|}{ Lutjanidae } \\
\hline Lutjanus synagris* & 770 & 354 & 259 & 1.4 & 0.46 & 0.02 \\
\hline Ocyurus chrysurus* & 619 & 272 & 177 & 1.5 & 0.44 & 0.02 \\
\hline Rhomboplites aurorubens* & 487 & 254 & 228 & 1.1 & 0.52 & 0.02 \\
\hline Lutjanus jocu* $*$ & 315 & 60 & 109 & 0.6 & 0.19 & 0.02 \\
\hline Lutjanus analis & 102 & 5 & 16 & 0.3 & 0.05 & 0.02 \\
\hline Lutjanus vivanus & 38 & 19 & 16 & 1.2 & 0.49 & 0.08 \\
\hline \multicolumn{7}{|l|}{ Serranidae } \\
\hline Cephalopholis fulva* & 750 & 623 & 107 & 5.8 & 0.83 & 0.01 \\
\hline Epinephelus morio* & 302 & 131 & 33 & 4.0 & 0.43 & 0.03 \\
\hline Mycteroperca bonaci* & 116 & 22 & 12 & 1.8 & 0.19 & 0.04 \\
\hline Cephalopholis furcifer & 15 & 9 & 6 & 1.5 & 0.60 & 0.13 \\
\hline Mycteroperca venenosa & 8 & 2 & 2 & 1.0 & 0.25 & 0.15 \\
\hline Alphestes afer & 6 & 5 & 0 & & 0.83 & 0.15 \\
\hline
\end{tabular}

TABLE 2. - Summary of the ANCOVA results with female log-transformed gutted weight (GW) as covariate, month as the main effect, and $\log$-transformed gonad weight as dependent variable (ns non-significant $\mathrm{p}>0.10, * \mathrm{p} \leq 0.10, * * \mathrm{p} \leq 0.5$ ).

\begin{tabular}{|c|c|c|c|c|c|c|c|c|}
\hline Species & $\begin{array}{l}\text { Log (gutted weight) } \\
\text { MS }\end{array}$ & $\mathrm{F}$ & $\begin{array}{l}\text { Month } \\
\text { MS }\end{array}$ & $\mathrm{F}$ & $\mathrm{df}$ & $\begin{array}{c}\text { Residuals } \\
\text { MS }\end{array}$ & $\mathrm{df}$ & $\mathrm{R}^{2}$ \\
\hline \multicolumn{9}{|l|}{ Lutjanidae } \\
\hline Lutjanus synagris & 130.65 & $280.02 * *$ & 7.68 & $16.46 * *$ & 25 & 0.47 & 337 & 0.67 \\
\hline Ocyurus chrysurus & 437.74 & $649.25 * *$ & 23.71 & $35.17 * *$ & 12 & 0.67 & 315 & 0.77 \\
\hline Rhomboplites aurorubens & 29.65 & $153.31 * *$ & 6.25 & $32.32 * *$ & 17 & 0.19 & 234 & 0.75 \\
\hline Lutjanus jocu & 27.50 & $34.90 * *$ & 27.50 & $9.12 * *$ & 13 & 0.79 & 45 & 0.70 \\
\hline \multicolumn{9}{|l|}{ Serranidae } \\
\hline Cephalopholis fulva & 34.84 & $73.85 * *$ & 32.15 & $68.15 * *$ & 15 & 0.47 & 566 & 0.73 \\
\hline Epinephelus morio & 38.39 & $33.82 * *$ & 7.77 & $6.84 * *$ & 19 & 1.14 & 110 & 0.60 \\
\hline Mycteroperca bonaci & 0.826 & $0.60^{\mathrm{ns}}$ & 3.06 & $2.23 *$ & 9 & 1.37 & 11 & 0.65 \\
\hline
\end{tabular}

spring to summer, with maximum GSI values recorded from September to March (Fig. 2). Spawning of Lutjanus jocu and Ocyurus chrysurus spanned from the Southern Hemisphere winter to spring, with maximum GSI values observed from June to October and from August to October respectively. A smaller GSI peak was also detected between February and March for both $L$. jocu and $O$. chrysurus. In contrast with the three aforementioned lutjanids that occur in shallow coastal areas, spawning of the deep-reef dweller Rhomboplites aurorubens occurred between the Southern Hemisphere summer and early autumn, with maximum GSI values from February to April (Fig. 2). Maturity data for the two rarer lutjanids are summarized in Table 1. Five mature females of Lutjanus analis were collected, three in June 2006, one in November 2006 and one in March 2007. No mature Lutjanus vivanus individuals were collected.

The three serranids for which a sufficient sample size was obtained are protogynous hermaphrodites, with gonads functioning first as ovaries and then transforming into testes (e.g. Brulé et al., 2003; GiménezHurtado et al., 2003), resulting in sex ratios that are biased towards smaller females (Table 1). Spawning in these species extended from the Southern Hemisphere winter to spring, with GSI values peaking from June to September for Cephalopholis fulva and Epinephelus morio, and from August to September for Mycteroperca bonaci (Fig. 2). For these three species, the inclusion of non-immature males in the analyses did not affect the results. The maturity data for the rarest serranids are summarized in Table 1. Seven mature Cephalopholis furcifer females were collected in August and October 2005. Two mature Mycteroperca venenosa females were collected in September 2006. Two mature Alphestes afer females were collected in June and another one (spent) in November 2005.

Size at maturity $\left(\mathrm{L}_{50}\right)$ was estimated separately for each sex and is summarized in Table 4 for the six most common species. Maturity ogives are presented in detail in Figure 4. The small sample sizes of the remaining rarer species made it impossible to estimate $\mathrm{L}_{50}$, but there are relevant clues from the material examined. For Rhomboplites aurorubens, the smallest non-immature specimens were 14.7 (female) and 16.5 $\mathrm{cm}$ SL (male), while the largest immature specimens were 17.5 (female) and $15.3 \mathrm{~cm} \mathrm{SL}$ (male), which suggests that $\mathrm{L}_{50}$ would be close to these values (Table 4). Similarly, $\mathrm{L}_{50}$ for Lutjanus analis_may range from 31.2 to 40 (females) and from 28.9 to $29.5 \mathrm{~cm}$ SL (males); for Lutjanus vivanus, $\mathrm{L}_{50}$ may range from 23.7 to 26 (females) and from 22.7 to $24 \mathrm{~cm}$ SL (males); for Mycteroperca venenosa, $\mathrm{L}_{50}$ for females is likely to be between 49.5 and $63 \mathrm{~cm} \mathrm{SL}$. For Cephalopholis furcif$e r$, the smallest non-immature female was $18.5 \mathrm{~cm} \mathrm{SL}$, but no immature individuals were found. Only females 

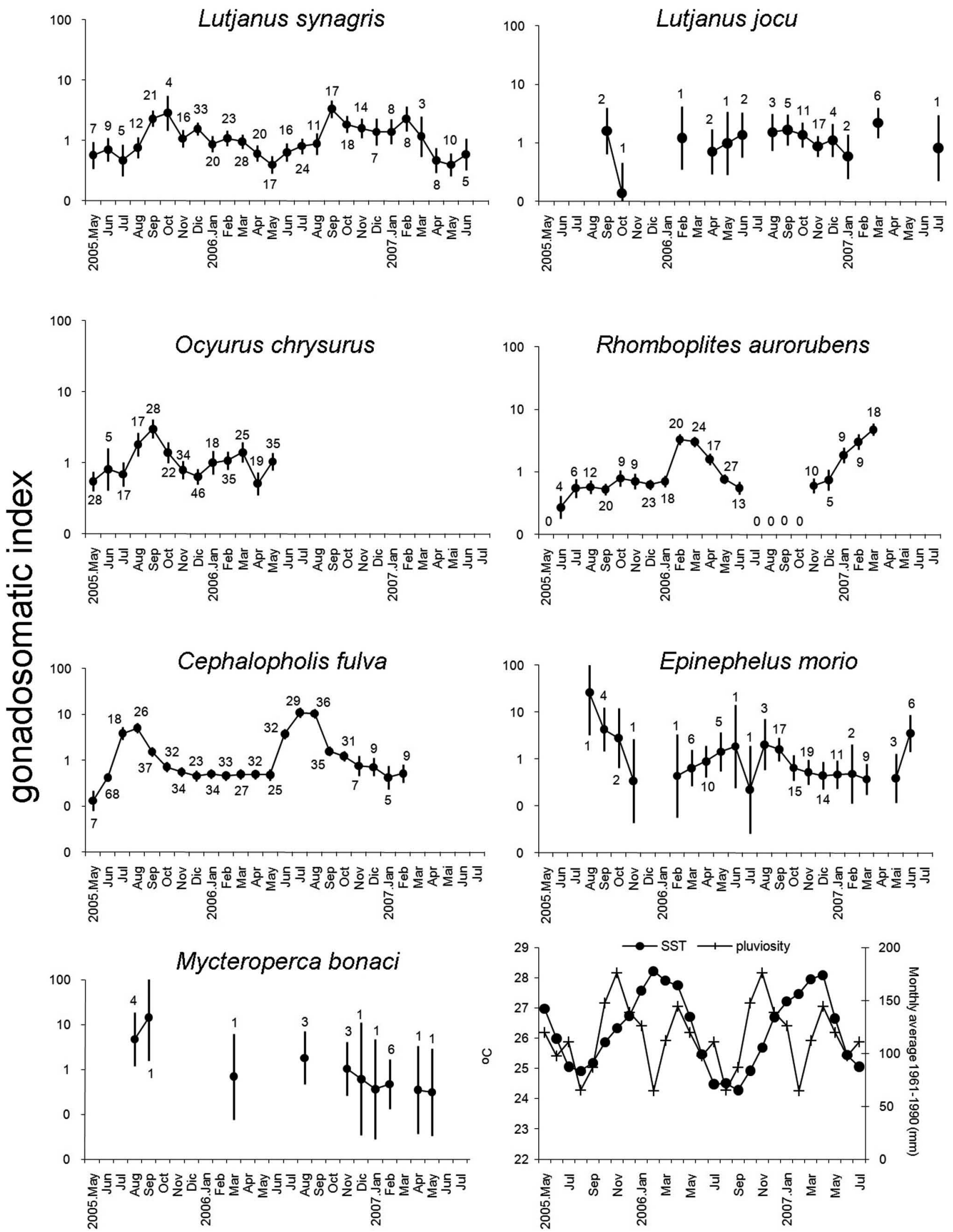

FIG. 2. - Temporal variation in the Gonadosomatic Index (GSI) for seven commercially important reef fish species, as well as for air temperature and rainfall. Estimates of the expected GSI values (dots) and their $95 \%$ confidence limits (bars). 

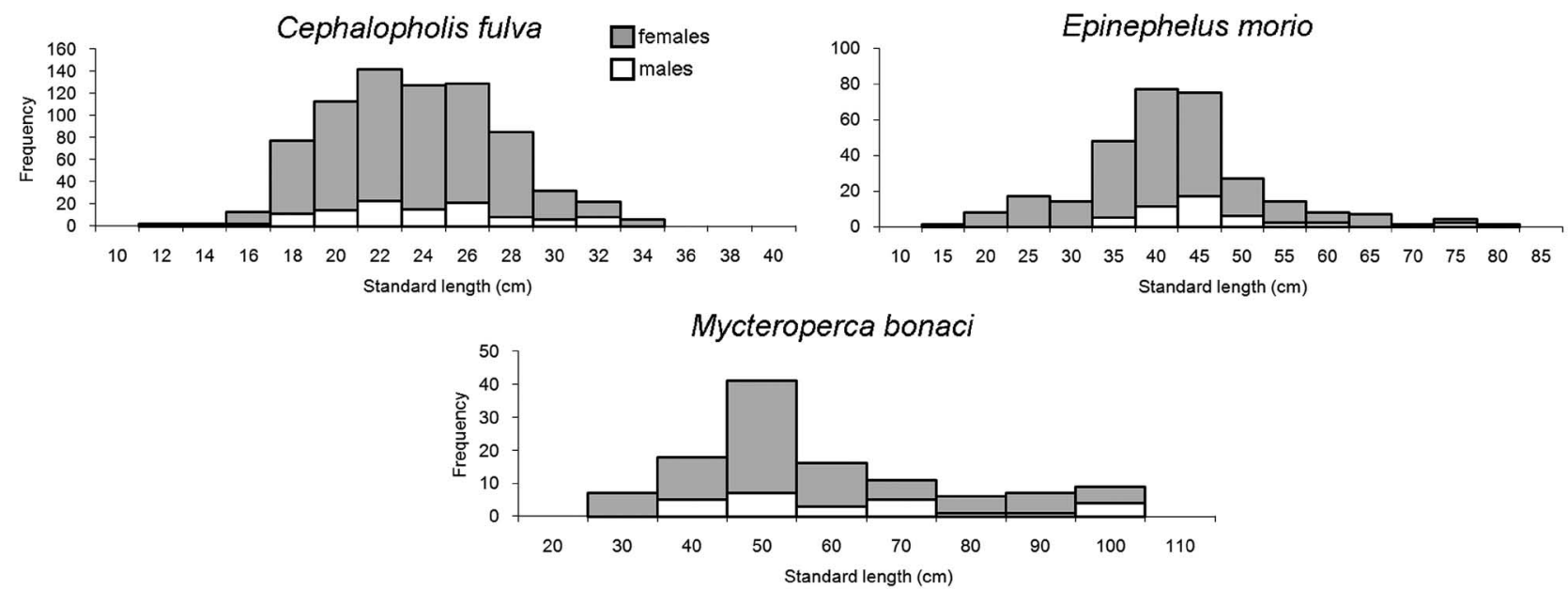

FIG. 3. - Proportion of males and females in different size categories for three commercially important reef fish species.
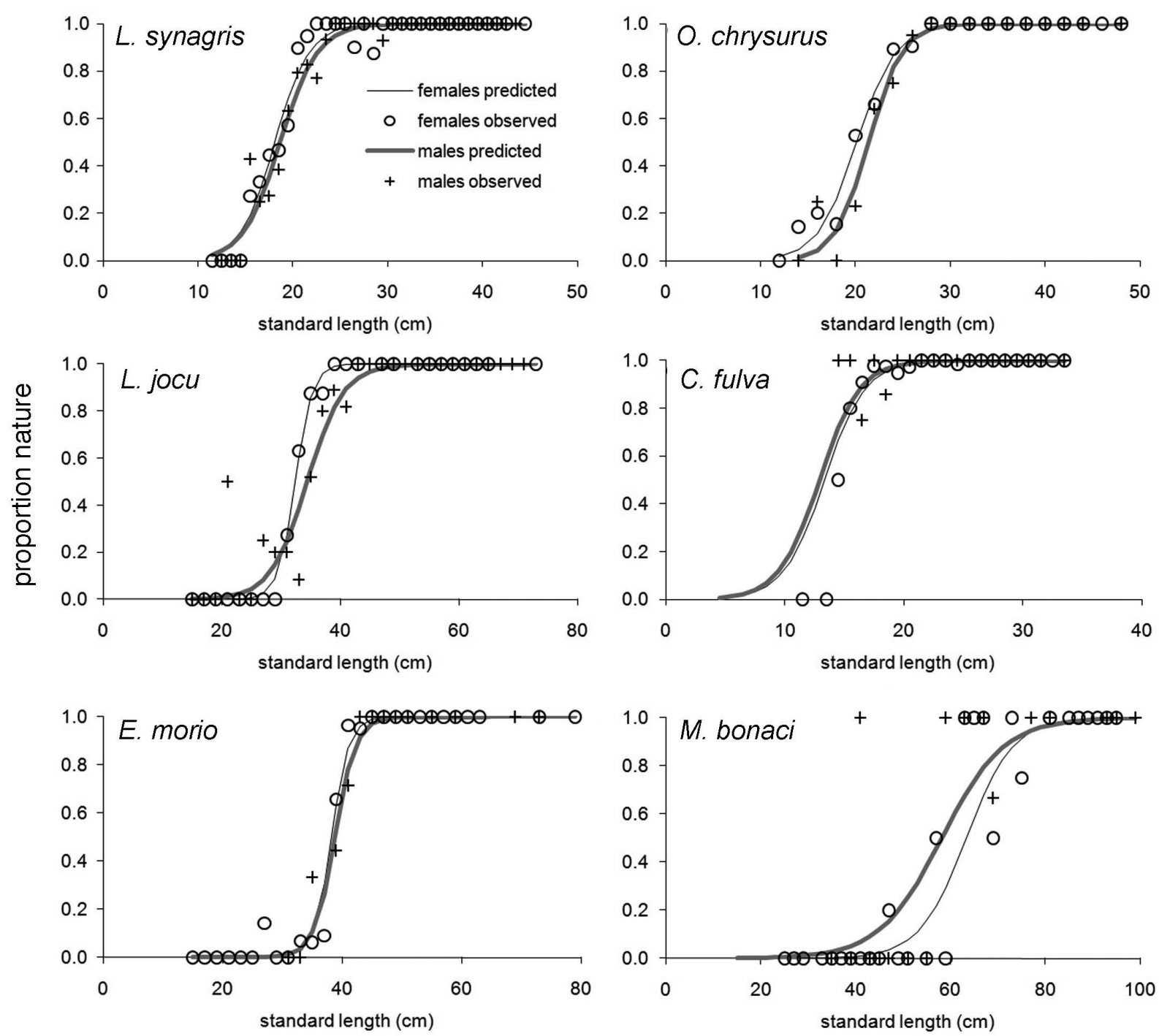

FIG. 4. - Observed and predicted values of size at maturity $\left(\mathrm{L}_{50}\right)$ for the six most common commercially important reef fish species in the study region. 
TABLE 3. - Size range, Standart Length-Weight (SL-W) and Total Length - Standard Length (TL-SL) relationships for the eleven most common lutjanids and serranids studied in the Abrolhos Bank, Brazil.

\begin{tabular}{|c|c|c|c|c|c|c|c|}
\hline \multirow[t]{2}{*}{ Species } & \multirow{2}{*}{$\begin{array}{l}\text { ndard length }(\mathrm{mm}) \\
\text { range }\end{array}$} & \multicolumn{2}{|c|}{$\log (\mathrm{W}) \sim \log (\mathrm{SL})$} & \multicolumn{2}{|c|}{$\mathrm{TL} \sim \mathrm{SL}$} & \multicolumn{2}{|c|}{$\mathrm{SL} \sim \mathrm{TL}$} \\
\hline & & intercept & slope & intercept & slope & intercept & slope \\
\hline \multicolumn{8}{|l|}{ Lutjanidae } \\
\hline Lutjanus synagris & $11.4-45.3$ & -2.93256 & 2.79322 & 1.33393 & 1.21109 & -0.87414 & 0.81880 \\
\hline Ocyurus chrysurus & $12.1-50.3$ & -3.20386 & 2.85286 & 0.75278 & 1.36745 & 0 & 0.71749 \\
\hline Rhomboplites aurorubens & $13.7-37.0$ & -3.01855 & 2.80358 & 0.49616 & 1.27843 & 0 & 0.76828 \\
\hline Lutjanus јоси & $11.1-69.5$ & -3.00117 & 2.85376 & 1.80074 & 1.20823 & -1.22331 & 0.82149 \\
\hline Lutjanus analis & $13.7-70.0$ & & & & & & \\
\hline Lutjanus vivanus & $19.7-47.0$ & & & & & & \\
\hline \multicolumn{8}{|l|}{ Serranidae } \\
\hline Cephalopholis fulva & $11.9-33.6$ & -3.29401 & 2.95492 & 0.99399 & 1.16289 & -0.72689 & 0.85524 \\
\hline Epinephelus morio & $12.0-78.5$ & -3.51953 & 2.97117 & 2.20823 & 1.17718 & -1.23918 & 0.83637 \\
\hline Mycteroperca bonaci & $24.2-99.0$ & -3.54946 & 2.98008 & 2.20823 & 1.17718 & -1.23918 & 0.83637 \\
\hline Cephalopholis furcifer & $18.5-27.4$ & & & & & & \\
\hline Mycteroperca venenosa & $30.1-65.0$ & & & & & & \\
\hline
\end{tabular}

TABLE 4. - Summary data for the most frequent species of snapper (Lutjanidae) and groupers (Serranidae) in the Abrolhos Bank reef fisheries.

\begin{tabular}{|c|c|c|c|c|c|c|c|c|c|}
\hline \multirow[t]{2}{*}{ Species } & \multirow{2}{*}{\multicolumn{2}{|c|}{$\begin{array}{l}\text { mallest non-immature } \\
\text { specimen }(\mathrm{mm}) \\
+\end{array}$}} & \multirow{2}{*}{\multicolumn{2}{|c|}{$\begin{array}{l}\text { Largest immature } \\
\text { specimen }(\mathrm{mm})\end{array}$}} & \multicolumn{2}{|c|}{$\mathrm{L}_{50}(\mathrm{~mm})( \pm \mathrm{SE})$} & \multirow[t]{2}{*}{ Sampling period } & \multirow{2}{*}{\multicolumn{2}{|c|}{$\begin{array}{l}\text { Depth }(\mathrm{m}) \\
\text { Observed Literature } \\
\text { range (maximum) }\end{array}$}} \\
\hline & & & & & q & $\widehat{0}$ & & & \\
\hline \multicolumn{10}{|l|}{ Lutjanidae } \\
\hline Lutjanus synagris* & 15.7 & 15.5 & 21.5 & 23.3 & $18.11( \pm 0.36)$ & $18.67( \pm 0.39)$ & May 2005-Jun 2007 & $5-40$ & $400^{1}$ \\
\hline Ocyurus chrysurus* & 14.7 & 16 & 25.3 & 25.4 & $20.15( \pm 0.44)$ & $21.39(0.5$ & May 2005 & $5-150$ & $180^{1}$ \\
\hline Rhomboplites aurorubens* & s* 14.7 & 16.5 & 17.5 & 15.3 & 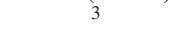 & 3 & May 2005-Mar 2007 & $15-150$ & $300^{1}$ \\
\hline Lutjanus jocu* & 30.5 & 26.6 & 36 & 40 & $32.42( \pm 0.49)$ & $34.42(0.74)$ & May 2005-Jul 2007 & $5-150$ & $40^{1}$ \\
\hline Lutjanus analis & 40 & 28.9 & 31.2 & 29.5 & 3 & 3 & May 2005-Mar 2007 & $5-200$ & $100^{1}$ \\
\hline Lutjanus vivanus & 23.7 & 24 & 26 & 22.7 & 3 & 3 & Set 2005-Dec 2006 & $40-300$ & $242^{1}$ \\
\hline \multicolumn{10}{|l|}{ Serranidae } \\
\hline Cephalopholis fulva* & 14.3 & 14.2 & 24.5 & 18.3 & $13.33( \pm 0.93)$ & $12.91( \pm 3.07)$ & May 2005-Feb 2007 & $40-150$ & $150^{2}$ \\
\hline Epinephelus morio* & 28 & 38.5 & 42.2 & 42 & $38.19( \pm 0.35)$ & $38.77( \pm 0.91)$ & 2005-Jul 2007 & $5-200$ & $330^{2}$ \\
\hline Mycteroperca bonaci* & 46.5 & 41.4 & 70 & 70 & $63.33( \pm 2.57)$ & $58.14( \pm 4.32)$ & May 2005-Jul 2007 & $5-300$ & $33^{2}$ \\
\hline Cephalopholis furcifer & 18.5 & 19 & & & & 3 & Jun 2005-Feb 2006 & $50-300$ & $100^{2}$ \\
\hline Mycteroperca venenosa & 63 & 46 & 49.5 & - & 3 & 3 & Jun 2005-Mar 2007 & $20-200$ & $137^{2}$ \\
\hline Alphestes afer & 18.4 & & 17.5 & - & 3 & 3 & Jun 2005-Abr 2006 & $40-150$ & $30^{2}$ \\
\hline
\end{tabular}

${ }^{1}$ Allen, $1985 ;{ }^{2}$ Heemstra and Randall, $1993 ;{ }^{3}$ small sample size precluded $\mathrm{L}_{50}$ estimation.

of Alphestes afer were collected, and the smallest nonimmature individual was $18.4 \mathrm{~cm}$ SL and the largest immature individual was $17.5 \mathrm{~cm}$ SL.

Size at sexual transformation for the three most common groupers is summarized in Figure 3, showing that Cephalopholis fulva begins to change sex before it reaches a size of $18 \mathrm{~cm}$ SL, Epinephalus morio before it reaches $35 \mathrm{~cm}$ SL and Mycteroperca bonaci after it reaches $40 \mathrm{~cm}$ SL. As expected for protogynous fish, the size distribution of males did not overlap with that of females in the smaller size classes.

\section{DISCUSSION}

\section{Spawning season}

Although spawning individuals of most tropical coastal fish species may be found year-round, there may be discernible regional patterns of reproductive timing in snappers and groupers (Munro, 1983; García-Cagide et al., 2001; Claro et al., 2009). The seasonal spawning patterns that we report here for the Abrolhos Bank are highly equivalent to those known for the western North Atlantic and are compatible with the results of other studies from Brazil. Potential biases due to the lack of histological analyses for confirming the macroscopically assessed maturity stages were minimized by our two-year sampling period, as the second year corroborated the results from the previous year in all cases.

In Abrolhos, the maximum GSI values for Lutjanus synagris ranged from late winter (September) to late summer (March). This result is fully compatible with the results from Gesteira and Rocha (1976) and partially matches the findings of Sousa-Junior. et al. (2008), who found a secondary peak in spring (AugustNovember) and a more pronounced peak during the summer (January-March), when we detected only a secondary GSI peak in Abrolhos $\left(17^{\circ} \mathrm{S}\right)$ (Fig. 2). Both Gesteira and Rocha (1976) and Sousa-Junior. et al. (2008) studied populations from Ceará State $\left(3-5^{\circ} \mathrm{S}\right)$, Brazil, and it is expected that some latitudinal variation occurs within regions/hemispheres (see Lutjanus jocu and Rhomboplites aurorubens below). In Cuba and Mexico, L. synagris is reported to spawn from late winter to early autumn (García-Cagide et al., 2001), in May in the Gulf of Batabano and the northwest shelf, and in June in the south and northeast zones of the Cuban platform (Claro and Lindeman, 2003; Claro et al., 2009); while, in Venezuela, most reproductive activity for this species is reported from the early sum- 
mer (July) to mid-autumn (November) (Gómez et al., 2001), in agreement with the idea that spawning peaks can vary within regions.For Lutjanus jocu and Ocyurus chrysurus, the GSI peaks in Abrolhos ranged from late autumn to early spring (June to October). While there are no data for other Brazilian populations of $L$. jocu, the spring reproductive peak that was reported for $O$. chrysurus by Costa et al. (2005) in Porto Seguro (the northern part of the Abrolhos Bank) was in full agreement with our data. Compared with Caribbean seasonal spawning patterns (Claro, 1983; Munro, 1983; Polovina and Ralston, 1987; García-Cagide et al., 2001; Claro et al., 2009), the spawning seasons that we observed only partially overlap, as both $L$. jocu and $O$. chrysurus tend to spawn in the Northern Hemisphere between late winter and early autumn (i.e. February to October). For $O$. chrysurus, the spawning peak in the Gulf of Batabano was observed during May and June, while in the northwest region of Cuba, it occurs in April and May (Claro, 1983).

In contrast with the more coastal lutjanids, the GSI values for the deeper-dwelling species Rhomboplites aurorubens peaked in Abrolhos between the Southern Hemisphere summer and autumn (February to May). While there have not been any reproductive studies on $R$. aurorubens in Brazil, in the Southern United States and eastern Gulf of Mexico this species is known to spawn between spring and late summer (May to September) (Cuellar et al., 1996; Hood and Jonshon, 1998), and $R$. aurorubens spawns throughout the year in Trinidad and Tobago (Manickchand-Heileman and Phillip, 1999). Higher reproductive activity was found to be associated with the wet season in Trinidad and Tobago, from June to November (Manickchand-Heileman and Phillip, 1999). While seasonal variation in water temperature may be the predominant spawning trigger at higher latitudes, factors such as rainfall may explain some of the latitudinal or regional incongruence in spawning patterns in tropical regions. In Abrolhos, there is a strong correspondence between spawning and rain/temperature peaks for R. aurorubens (Fig. 2). However, it is currently impossible to discriminate between the many potentially interacting environmental factors that influence intraand inter-regional seasonal reproductive patterns of $R$. aurorubens and of the other species in this study. The factors involved may include water temperature, photoperiod, food abundance, temperature, rainfall (which affects the salinity in coastal areas) and the strength of prevailing currents (Wootton, 1998).

In Abrolhos, the reproductive peaks of serranids were much more homogeneous than those found for lutjanids, which had maximum GSI values recorded between the Southern Hemisphere winter and spring (June to September) for Cephalopholis fulva, Epinephelus morio and Mycteroperca bonaci. For $M$. bonaci, which is the only tropical grouper species for which there are spawning data from Brazil, Teixeira et al. (2004) recorded coincident spawning peaks between 2 and $10^{\circ} \mathrm{S}$, with females being fertile between
August and September. The breeding seasons of these three serranids in Brazil largely correspond to those that have been recorded in the Northern Hemisphere (Smith, 1961; Moe, 1969; Munro, 1983; García-Cagide and García, 1996; Brulé et al., 1999; Giménez-Hurtado et al., 2003; Burgos et al., 2007), where they also tend to spawn from late autumn to early spring (December to April). Information from larval assemblages that have been studied on the Abrolhos Bank (Nonaka et al., 2000) shows the increased abundance of larval groupers during the winter, when they are among the five most abundant larval fish families. Larval snappers are rare throughout the year (Nonaka et al., 2000), which could reflect their larval behavioural characteristics and cross-shelf distribution.

Although the spawning periods of the rarer species could not be estimated precisely based on our data, there is some agreement between the data that have been reported in the literature from the Northern Hemisphere and the few mature specimens of Lutjanus analis, Alphestes afer, Mycteroperca venenosa and Cephalopholis furcifer that we collected in Abrolhos. As there are no other data from Brazil, the fragmentary information presented herein is useful as a base for preliminary comparison. Additional studies may confirm that $L$. analis spawns between spring and autumn in the Southern Hemisphere (reported to spawn from April to August in Cuba; Claro et al., 2001; Claro et al., 2009), while the grouper species $A$. afer, $M$. venenosa and $C$. furcifer spawn during the Southern Hemisphere winter (reported to spawn between December and May in the Caribbean; Thompson and Munro, 1974).

\section{Size at maturity}

The smallest size class at which $50 \%$ of fish were sexually mature $\left(\mathrm{L}_{50}\right)$ for Lutjanus synagris (18.1-18.7 $\mathrm{cm}$ SL for females and males respectively) is similar to records from the central Caribbean (Thompson and Munro, 1974; Claro et al., 2001) and is slightly smaller than the size reported in Venezuela (Gómez et al., 2001) and Bermuda (Luckhurst et al., 2000). The values reported by Sousa-Junior et al. (2008) from Ceará State $\left(3-5^{\circ} \mathrm{S}\right)$, Brazil, completely agree with our estimates. For Ocyurus chrysurus, our $\mathrm{L}_{50}$ estimates ranged between 20.2 and $21.4 \mathrm{~cm}$ SL (females and males), but it is difficult to compare our results with those from previous studies as published records vary greatly, and range from 13-17 cm FL (Piedra-Catañeda, 1965; Claro et al., 2001) to $26 \mathrm{~cm}$ FL (Thompson and Munro, 1974). In the northern part of the Abrolhos Bank, Costa et al. (2005) reported an $\mathrm{L}_{50}$ ranging from 18.6 to $22.4 \mathrm{~cm}$ FL, which is very close to our estimates. For Lutjanus jocu, our $\mathrm{L}_{50}$ estimates (32.4-34.4 $\mathrm{cm}$ SL for females and males) are similar to those from the Central Caribbean (Thompson and Munro, 1974) and slightly lower than those from Cuba (GarcíaCagide et al., 2001: 43-48 cm FL). Thompson and Munro (1974) suggested that Cephalopholis fulva at- 
tains maturity before reaching $16 \mathrm{~cm}$ TL, which is very similar to our estimates for Abrolhos (13.33-12.91 cm SL, females and males). For Epinephelus morio, our $\mathrm{L}_{50}$ estimates (38.2-38.8 $\mathrm{cm} \mathrm{SL}$, females and males) are comparable to data from the Caribbean (Burgos et al., 2007: $48.7 \mathrm{~cm} \mathrm{TL}$ ), and for Mycteroperca bonaci, our $\mathrm{L}_{50}$ estimates (58.1-63.3 cm SL, females and males) are comparable to data from Florida (Crabtree and Bullock, 1998: $50.8 \mathrm{~cm}$ TL), Cuba (García-Cagide and García, 1996: $57 \mathrm{~cm} \mathrm{TL}$ ) and Mexico (Brulé et al., 2003: $72.1 \mathrm{~cm}$ TL) (females only). In addition to being influenced by intrinsic regional variation, the $\mathrm{L}_{50}$ may also be affected by external factors such as exploitation level, as has been reported for L. synagris in Cuba by Claro et al. (2001), who compared shifts in the timing of sexual maturity that occurred in Cuba between 1960 and 1972 due to overfishing $\left(\mathrm{L}_{50}\right.$ shifted from 13-16 to $18-20 \mathrm{~cm} \mathrm{FL}$ ). The estimates that we present here provide a broad comparative baseline for Brazil and for future assessments in the Abrolhos Bank.

Although the length at the time of sexual transition for $50 \%$ of the population was not estimated in the present study (e.g. Crabtree and Bullock, 1998; Brulé et al., 2003), the minimum sizes of Cephalopholis fulva and Epinephelus morio in Abrolhos that we measured for them to have undergone sexual transition were very similar to values from the Caribbean. C. fulva and $E$. morio begin sexual transition at approximately 18 and $35 \mathrm{~cm}$ SL in Abrolhos (22 and $45 \mathrm{~cm}$ TL in the Caribbean and the southern United States) (Thompson and Munro, 1974; Burgos et al., 2007). However, Mycteroperca bonaci begins changing sex in Abrolhos only after reaching $40 \mathrm{~cm} \mathrm{SL}$, which differs from observations from the southern Gulf of Mexico (Brulé et al., 2003: 85 $\mathrm{cm}$ FL) but is closer to the smallest size for transitional M. bonaci from northeastern Brazil (64 cm FL) that was reported by Teixeira et al. (2004). In this case, histological corroboration of our results will be necessary before this geographical variation in size at the time of sexual transition can be confirmed. It is worth noting that fishing of these species is concentrated on immature or only recently matured individuals (see Figs. 3 and 4), which may compromise the long-term sustainability of these fisheries (Myers and Mertz 1998; Claro et al., 2001, 2009; Claro and Lindeman, 2004).

Similarly to what was observed by Crabtree and Bullock (1998) and Brulé et al. (2003), we also observed sexual dimorphism in Mycteroperca bonaci in Abrolhos. Fin pigmentation was not recorded in all specimens, but jet black pigmentation on the fin was confirmed in at least some of the large males from Brazil.

\section{Conservation and fishery implications}

The most abundant snapper-grouper species that we assessed, including Lutjanus synagris, Lutjanus jocu, Ocyurus chrysurus, Epinephelus morio and Mycteroperca bonaci, are well known to form spawning aggre- gations in the Caribbean (Claro and Lindeman, 2003; Claro et al., 2009; Sadovy de Mitcheson et al., 2008). The location and protection of the sites where most spawning occurs over a few months each year would be one of the most significant conservation measures that can be undertaken for these species (Sadovy de Mitcheson et al., 2008). The problem behind implementing these policies lies in the fact that there is no information on the location of the spawning sites of most snappers and groupers, particularly in the regions of large, complex continental shelf environments, such as the Royal Charlotte and Abrolhos Banks in Brazil. Under these circumstances, precautionary management measures need to be implemented even before spawning sites are located and protected. Spawning aggregations, as defined by Colin et al. (2003), have not been recorded in Abrolhos until now. However, before we began biological sampling for this study, 30 experienced fishermen were interviewed and were asked specifically whether and when each of the studied species spawns and/or forms aggregations. Responses varied, with less than $50 \%$ correspondence between the observed GSI peaks and the responses from fishermen with respect to breeding seasons, with the exception of $L$. synagris and $O$. chrysurus, for which there was more than $90 \%$ correspondence. Information about spawning aggregations was even more ambiguous, with the exception of $O$. chrysurus, for which there is well-established knowledge among local fishermen of a spawning ground in the southern part of the Abrolhos Bank. Further assessments in this area are underway to confirm the existence and the characteristics of this potential spawning aggregation site. With the exception of jewfish spawning aggregations in Santa Catarina State (Gerhardinger et al., 2009), there is only speculation on the timing and location of snapper-grouper spawning aggregations in Brazil (Teixeira et al., 2004; Costa et al., 2003, 2005).

All of the species within the snapper-grouper complex were reported by nearly all the interviewed fishermen to have been previously more abundant in the Abrolhos Bank, including Lutjanus cyanopterus, Mycteroperca venenosa and Epinephelus itajara, which were nearly absent from our samples. Previous stock assessments in the study region (Klippel et al., 2005) indicate that Ocyurus chrysurus and Rhomboplites aurorubens have been severely overfished, and Lutjanus jocu and Lutjanus vivanus are currently subjected to maximum levels of fishing mortality, while only Lutjanus synagris and Lutjanus analis are only moderately over-exploitated. A similar exploitation situation has been reported for northeastern Brazil between 4 and $13^{\circ} \mathrm{S}$ (Frédou et al., 2009a, b). Grouper stocks have never been assessed in Brazil, but their state may be even worse than that of snappers (Teixeira et al., 2004).

Besides the implementation of subsidies (Abdallaha and Sumaila, 2007), there has never been a significant public policy for managing reef fisheries in Brazil (e.g. 
catch or effort limitations), with the following exceptions: a country-wide ban on catching Epinephelus itajara since 2002, size limits for Lutjanus purpureus in northern and northeastern Brazil, and size limits for Epinephelus niveatus, Mycteroperca marginata and Mycteroperca acutirostris in southern and southeastern Brazil. Coastal environmental and fishery management in the Abrolhos region, which contains the largest and richest South Atlantic reef system, is centred on Marine Protected Areas (MPAs) under no-take ( 890 $\mathrm{km}^{2}$ ) and multiple-use regimes ( 2908 km²) (Fig. 1). There is growing evidence of the positive effects for Abrolhos of zoning and management within MPAs (Moura et al., 2007; Francini-Filho and Moura, 2008a), and spillover of snappers and groupers from no-take zones has been demonstrated on a local scale (hundreds of meters) (Francini-Filho and Moura, 2008b). However, the present as well as other studies suggest that managing reef fisheries only within the existing MPAs will not reverse the current declining trend.

Though the MPA networks do not encompass all if any of the spawning aggregation sites (generally deep reefs near the shelf break; Sadovy de Mitcheson et al., 2008), and larger snapper-groupers are caught far outside the MPA limits (see Table 4; note that no MPA reaches depths $>20 \mathrm{~m}$ ) and in areas that benefit from $\mathrm{sp}$ illover from no-take zones (Francini-Filho and Moura, 2008b), the buffer zones that have been proposed around MPAs should provide an adequate framework for managing reef fisheries. Within Brazilian legislation consultative and deliberative councils must be set up for MPAs, with their jurisdiction extending over the buffer zones. Councils are one of the few instances in which the people managing fisheries receive direct and continuous input from fishermen, and this is especially true in Extractive Reserves, where the councils are deliberative (e.g. Corumbau, Cassurubá, and Canavieiras in the Abrolhos Region). These co-management arrangements are some of the few success stories of small-scale fisheries management in Brazil (Seixas et al., 2009). It is important to highlight that the implementation of buffer zones would facilitate establishing both spatial (e.g. new no-take areas covering spawning sites) and temporal (e.g. seasonal closures) management tools. In fact, because no spawning aggregation sites are currently known, seasonal closures during spawning peaks may be a more effective alternative. The information provided herein regarding lengths at first sexual maturity and spawning periods can therefore be readily incorporated into management plans for MPAs (see Moura et al., 2007; Francini-Filho et al., 2008a, b).

The $\mathrm{L}_{50}$ estimates we calculated based on our observations were shown to more than 300 fishermen from six communities in 2007 (public meetings with 20 to 60 attendees), and there was a general consensus on the declining status of the snapper-grouper fisheries and on the need for setting minimum size limits for catches (maximum size limits were considered an unreach- able target). Restrictions on fishing during spawning peaks may be more complex to implement due to the non-selective nature of the snapper-grouper fisheries combined with their relatively long spawning seasons. Nonetheless, the species that we observed do exhibit discernible spawning peaks, and seasonal restrictions must at least be considered and further discussed among the stakeholders (September to October for lutjanids, except for Rhomboplites aurorubens, and July to August for serranids).

\section{ACKNOWLEDGEMENTS}

This study is a contribution from the Abrolhos Node of Conservation International's Marine Management Areas Science Program, funded by the Gordon and Betty Moore Foundation. Thanks to the Conservation Leadership Programme (formerly the BP Conservation Programme) for supporting this project with a grant in 2004, a National Geographic Society grant to Enric Sala, a Fundação de Amparo à Pesquisa do Estado da Bahia (FAPESB) grant to MOF, and a Conselho Nacional de Desenvolvimento Cientifico e Tecnológico (Cnpq) grant to CVMV. We acknowledge Juliane Cebola (Universidade Estadual de Maringá), Juliana Fonseca (Universidade Estadual Julio de Mesquita Filho), Paulo Costa (UNIRIO), Luis Frota (Instituto Chico Mendes de Conservação da Biodiversidade), Beatrice Ferreira and Sergio Rezende (Universidade Federal de Pernambuco), Mauricio Hostim-Silva (Universidade Federal do Espírito Santo), Les Kaufman (Boston University) and Enric Sala (Scripps Institution of Oceanography) for valuable suggestions throughout the study, and IBAMA/ICMBio for research permits. Guilherme Dutra (Conservation International) kindly reviewed a first draft of the manuscript. We are grateful to Igor Kintopp for preparing Figure 1.

\section{REFERENCES}

Abdallah, P.R. and U.R. Sumaila. - 2007. A historical account of Brazilian policy on fisheries subsidies. Mar. Policy., 31: 444-450.

Allen, G.R. - 1985. Snappers of the world: An annotated and illustrated catalogue of Lutjanid species know to date. FAO Fish. Synop., Rome.

Brulé, T., C. Déniel, T. Colás-Marrufo and M. Sánchez-Crespo. 1999. Red grouper reproduction in the southern Gulf of Mexico. Trans. Am. Fish. Soc., 128: 385-402.

Brulé, T., X. Renan, T. Colás-Marrufo, Y. Hauyon, A.N. Tuz-Sulub and C. Déniel. - 2003. Reproduction in the protogynous black grouper (Mycteroperca bonaci (Poey) from the southern Gulf of Mexico. Fish. Bull., 101: 463-475.

Burgos, J.M., G.R. Sedberry, D.M. Wyanski and P.J. Harris. - 2007. Life history of red grouper (Epinephelus morio) off the coasts of North Carolina and South Carolina. Bull. Mar. Sci., 80: 45-65.

Claro, R. - 1983. Ecología y ciclo de vida de la rabirrubia, Ocyurus chrysurus (Bloch), en la plataforma cubana. I. Identidad, distribución, hábitat, reproducción y alimentación. Rep. Invest. Inst. Oceanol. Acad. Cienc. Cuba, 15: 1-34.

Claro, R. and K.C. Lindeman. - 2003. Spawning aggregation sites of snnaper and grouper species (Lutjanidae and Serranidae) on the insular shelf of Cuba. Gulf Carib. Res., 14: 91-106.

Claro, R. and K.C. Lindeman. - 2004. Biología y manejo de los pargos (Lutjanidae) en el Atlántico occidental. Instituto de 
Oceanología, Citma, La Habana. En CD-ROM. ISBN: 878959-298-011-2. Available on line at: http://www.redciencia.cu.

Claro, R., K.C. Lindeman and L.R. Parenti. - 2001. Ecology of the marine fishes of Cuba. Smithsonian Institution Press, Washington.

Claro, R., Y. Sadovy de Mitcheson, K.C. Lindeman and A. GarcíaCagide. - 2009. Historical analysis of commercial Cuban fishing effort and the effects of management interventions on important reef fishes: 1960-2005. Fish. Res., 99(1): 7-16.

Coleman, F.C., C.C. Koenig, A.M. Eklund and C.B. Grimes. 1999. Management and conservation of temperate reef fishes in the grouper-snapper complex of the southeastern United States. Am. Fish. Soc. Symp., 23: 244-242.

Coleman, F.C., C.C. Koenig, G.R. Huntsman, J.A. Musick, A.M. Eklund, J.C. McGovern, R.W. Chapman, G.R. Sedberry and C.B. Grimes. - 2000. Long-lived reef fishes: The groupersnapper complex. Fisheries, 25: 14-20.

Colin, P.L., Y. Sadovy and M.L. Domeier. - 2003. Manual for the study and conservation of reef fish spawning aggregations. Society for the Conservation of Reef Fish Aggregations Special Publication. No. 1 (Version 1.0)

Cordell, J. - 2006. Brazil: Dynamics and challenges of marine protected area development and coastal protection. In: Scaling up marine management: The role of marine protected areas. The World Bank, Washington

Costa, P.A.S., A.C. Braga and L.O.F. Rocha. - 2003. Reef fisheries in Porto Seguro, eastern Brazilian coast. Fish. Res., 60: 577-583.

Costa, P.A.S., A.S. Martins and G. Olavo. - 2005. Pesca e potenciais de exploração de recursos vivos na região central da Zona Econômica Exclusiva brasileira. Museu Nacional, Rio de Janeiro.

Crabtree, R.E and L.H. Bullock. - 1998. Age, growth and reproduction of black grouper, Mycteroperca bonaci, in Florida waters. Fish. Bull., 95: 735-753.

Cuellar, N., G.R. Sedberry and D.M. Wyanski. - 1996. Reproductive seasonality, maturation, fecundity, and spawning frequency of the vermilion snapper Rhomboplites aurorubens, off the southeastern United States. Fish. Bull., 94: 635-653.

Francini-Filho, R.B. and R.L. Moura. - 2008a. Dynamics of fish assemblages on coral reefs subjected to different management regimes in the Abrolhos Bank, eastern Brazil. Aquat. Conserv. 18: 1166-1179.

Francini-Filho, R.B. and R.L. Moura. - 2008b. Evidence for spillover of reef fishes from a no-take marine reserve: An evaluation using the before-after control-impact (BACI) approach. Fish. Res., 93: 346-356.

Frédou, T. and B.P. Ferreira. - 2005. Bathymetric trends of Northeastern Brazilian snappers (Pisces, Lutjanidae): Implications for the reef fishery dynamic. Braz. Arch. Biol. Tech., 48: 787-800.

Frédou, T., B.P. Ferreira and Y. Letourneur. - 2006. A univariate and multivariate study of reef fisheries off northeastern Brazil. J. Mar. Sci., 63: 883-896.

Frédou, T., B.P. Ferreira and Y Letourneur. - 2009a. Assessing the stocks of the primary snappers caught in Northeastern Brazilian reef systems. 1: Traditional modelling approaches. Fish. Res., 99: 90-96.

Frédou, T., B.P. Ferreira and Y. Letourneur. - 2009b. Assessing the stocks of the primary snappers caught in Northeastern Brazilian reef systems. 2 - A multi-fleet age-structured approach. Fish. Res., 99: 97-105.

Furtado-Júnior, I. and C.S.F. Brito. - 2002. Biologia e pesca do pargo Lutjanus purpureus, Poey, 1875 (Pisces: Lutjanidae), na região Norte do Brasil. Bol. Téc. Cient. Cepnor., 2(1): 173-190.

García-Cagide, A. and T. García. - 1996. Reproducción de Mycteroperca bonaci y Mycteroperca venenosa (Pisces: Serranidae) en la plataforma Cubana. Rev. Biol. Trop., 44: 771-780.

García-Cagide, A., R. Claro and B.V. Koshelev. - 2001. Reproductive patterns of fishes of the Cuban shelf. In: R. Claro, K.C. Lindeman and L.R. Parenti (eds.), Ecology of the marine fishes of Cuba. pp 71-102. Smithsonian Institution Press, Washington, D.C.

Gerhardinger, L.C., M. Hostim-Silva, R.P. Medeiros, J. Matarezi, A.A. Bertoncini, M.O. Freitas and B.P. Ferreira. - 2009. Fishers' resource mapping and goliath grouper Epinephelus itajara (Serranidae) conservation in Brazil. Neot. Ichthyol., 7: 93-102.

Gesteira, T.C.V. and C.T.C. Ivo. - 1973. Estudo da reprodução e fecundidade do pargo Lutjanus purpureus Poey, do Norte e Nordeste do Brasil. Arq. Cienc. Mar., 13(2): 109-112.

Gesteira, T.C.V. and C.A.S. Rocha. - 1976. Estudo sobre a fecun- didade do ariocó, Lutjanus synagris (Linnaeus), da costa do estado do Ceará (Brasil). Arq. Cienc. Mar., 16(1): 19-22.

Gimenez-Hurtado, E., V.M.C. Garcia, R.B. Rosas and S.A. Chiroldes. - 2003. Reproducción y fecundidad de la cherna americana (Epinephelus morio) en el Banco de Campeche, México. Oceánides, 18: 13-21.

Gobert, B., P. Berthou, E. Lopez, P. Lespagnol, M.D.O. Turcios, C. Macabiau and P. Portillo. - 2005. Early stages of snappergrouper exploitation in the Caribbean (Bay Islands, Honduras). Fish. Res., 73: 159-169.

Gómez, G., R. Guzmán and R. Chacón. - 2001. Parámetros reproductivos y poblacionales de Lutjanus synagris em el Golfo de Paria, Venezuela. Zootec. Trop., 19(3): 335-357.

Heemstra, P.C. and J.E. Randall. - 1993. Groupers of the world. FAO Species Catalogue 16, Rome.

Hood, P.B. and A.K. Johnson. - 1998. Age, growth and reproduction of vermilion snapper Rhomboplites aurorubens from the eastern Gulf of Mexico. Fish. Bull., 97: 828-841.

Klippel, S., G. Olavo, P.A.S. Costa, A.S. Martins, M.B. Peres. 2005. Avaliação dos estoques de lutjanídeos da costa central do Brasil: Análise de coortes e modelo preditivo de Thompson e Bell para comprimentos. In: P.A.S Costa, A.S. Martins and G. Olavo (eds.), Pesca e potenciais de exploração de recursos vivos na região central da Zona Econômica Exclusiva brasileira, pp. 83-98. Museu Nacional, Rio de Janeiro.

Luckhurst, B.E., M.J. Dean and M. Reichert. - 2000. Age, growth and reproduction of the lane snapper Lutjanus synagris (Pisces: Lutjanidae) at Bermuda. Mar. Ecol. Prog. Ser., 203: 255-261.

Manickchand-Heileman, S.C. and D.A.T Phillip. - 1999. Contribution to the biology of the vermilion snapper, Rhomboplites aurorubens, in Trinidad and Tobago, West Indies. Environ. Biol. Fish., 55: 413-421.

Menezes, N.A., P.A. Buckup, J.L. Figueiredo and R.L. Moura. 2003. Catálogo das espécies de peixes marinhos do Brasil. Museu de Zoologia, Universidade de São Paulo, São Paulo.

Moe, M.A. Jr. - 1969. Biology of the red grouper, Epinephelus morio (Valenciennes) from the eastern Gulf of Mexico. Flor. Dep. Nat. Res. Mar. Res. Lab., Prof. Pap. Ser., 10: 1-95.

Morris, A.V., C.M. Roberts and J.P. Hawkins. - 2000. The threatened status of groupers (Epinephelinae). Biodiversity Conserv. 9: 919-942.

Moura, R.L. - 2003. Brazilian reefs as priority areas for biodiversity conservation in the Atlantic Ocean. Proc. 9th Inter. Coral Reef Symp. 9(2): 917-920.

Moura, R.L. and R.B. Francini-Filho. - 2006. Reef and shore fishes of the Abrolhos Region, Brazil. In: G.F. Dutra, D.R. Allen, T. Werner and A.S. McKenna (eds.), A Rapid Marine Biodiversity Assessment of the Abrolhos Bank, Bahia, Brazil, pp. 40-55. Conservation International, Washington.

Moura, R.L. and K.C. Lindeman. - 2007. A new species of snapper (Perciformes: Lutjanidae) from Brazil, with comments on the distribution of Lutjanus griseus and L. apodus. Zootaxa, 1422: 31-43.

Moura, R.L., G.F. Dutra, R.B. Francini-Filho, C.V. Minte-Vera, I.B. Curado, F.J. Guimarães, R.F. Oliveira and D.C. Alves. - 2007. Fisheries Management in the Marine Extractive Reserve of Corumbau - Bahia. In: A.P. Prates and D. Blanc (eds.), Aquatic Protected Areas as Fisheries Management Tools, pp. 175-187. Ministério do Meio Ambiente, Brasília.

Munro, J.L. - 1983. Caribbean coral reef fishery resources. ICLARM Studies and Reviews, Manila.

Munro, J.L., V.C. Gaut, R. Thompson and P.H. Reeson. - 1973. The spawning season of Caribbean reef fishes. J. Fish. Biol., 5: 69-84.

Myers, R.A. and G. Mertz. - 1998. The limits of exploitation: a precautionary approach. Ecol. Appl., 8(1): 165-S169.

Nonaka, R.H., Y. Matsuura and K. Suzuki. - 2000. Seasonal variation in larval fish assemblages in relation to oceanographic conditions in the Abrolhos Bank region off eastern Brazil. Fish. Bull., 98: 767-784.

Otter-Research. - 2000. AD Model Builder Version 5.0.1 for use in nonlinear modeling and statistics. Available from Otter Research Ltd., PO Box 2040, Sidney BC V8L 3S3, and http:// otter-rsch.com/admodel.htm or http://admb-project.org/.

Pauly, D. - 2009. Beyond duplicity and ignorance in global fisheries. Sci. Mar., 73(2): 215-224.

Pauly, D., R. Watson and J. Alder. - 2005. Global trends in world 
fisheries: Impacts on Marine ecosystems and food security. Philos. Trans. R. Soc. Lond. B., 360: 5-12.

Piedra-Castañeda, G. - 1965. Materials on the biology of the yellowtail snapper, Ocyurus chrysurus (Bloch). In: A.S. Bogdanov (ed.), Joint Soviet-Cuban Fisheries Investigations, pp. 267-283. Moscow.

Polovina, J.J. and S. Ralston. - 1987. Tropical snappers and groupers: Biology and fisheries management. Westview Press, Boulder and London.

Rezende, S.M., B.P. Ferreira and T. Frédou. - 2003. A pesca de lutjanídeos no nordeste do Brasil: Histórico das pescarias, características das espécies e relevância para o manejo. Bol. Tec. Cient. Cepene., 11: 257-270.

Roa, R. - 1993. Annual growth and maturity function of the squat lobster Pleuroncodes monodon in Central Chile. Mar. Ecol. Prog. Ser., 97: 157-166.

Sadovy de Mitcheson, Y., A. Cornish, M. Domeier, P.L. Colin, M. Russell and K.C. Lindeman. - 2008. A global baseline for spawning aggregations of reef fishes. Conserv. Biol., 22: 1233-1244.

Seixas, C.S., C.V. Minte-Vera, R.G. Ferreira, R.L. Moura, I.B. Curado, J. Pezzuti, A.P.G. Thé and R.B. Francini-Filho. - 2009. Co-managing commons: Advancing Aquatic Resources Management in Brazil. In: P. Lopes and A. Begossi (eds.), Current Trends in Human Ecology, pp. 156-182. Cambridge Scholars Publishing, Newcastle-upon-Tyne, Northumberland.
Smith, C.L. - 1961. Synopsis of biological data on groupers (Epinephelus and allied genera) of the Western North Atlantic. FAO Fish. Biol. Synop., 23: 1-62.

Sousa-Junior, V.B., J.R.F. Silva and R. Salles. - 2008. Análise ovariana do ariacó, Lutjanus synagris (Actinopterygii: Lutjanidae), e considerações sobre sua reprodução no estado do Ceará. Arq. Cienc. Mar., 41: 90-97.

Souza, R.F.C., C.T.C. Ivo and R.A.L. Souza. - 2003. Aspectos da reprodução do pargo, Lutjanus purpureus (Poey, 1875), na costa Norte do Brasil. Bol. Téc. Cient. Cepnor., 3(1): 107-121.

Teixeira, S.F., B.P. Ferreira and I.P. Padovan. - 2004. Aspects of fishing and reproduction of the black grouper Mycteroperca bonaci (Poey 1860) (Serranidae: Epinephelinae) in the Northeastern Brazil. Neotrop. Ichthol., 2: 19-30.

Thompson, R. and J.L. Munro. - 1974. The biology, ecology and bioecomics of the snappers, Lutjanidae. In: J.L. Munro (ed.), Caribbean Coral Reef Fisheries Resources, pp. 94-109. International Center for Living Aquatic Resources Management, Manila.

Wootton, R.J. - 1998. Ecology of Teleost fishes. Kluwer Academic Publishers, Boston.

Scient. ed.: A. Garcia-Rubies.

Received November 13, 2009. Accepted June 16, 2010.

Published online January 10, 2011. 